This article was downloaded by: [TÜBTAK EKUAL]

On: 18 December 2008

Access details: Access Details: [subscription number 772814176]

Publisher Informa Healthcare

Informa Ltd Registered in England and Wales Registered Number: 1072954 Registered office: Mortimer House, 37-41 Mortimer Street, London W1T 3JH, UK

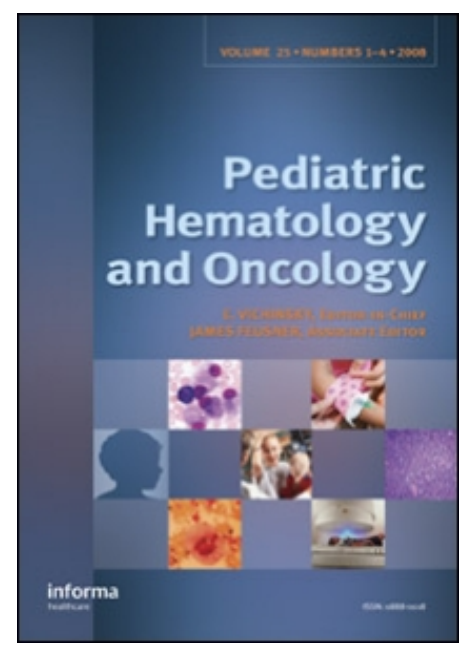

Pediatric Hematology and Oncology

Publication details, including instructions for authors and subscription information:

http://www.informaworld.com/smpp/title content=t713610311

\title{
DYSPLASIA AND DISORDER OF CELL MEMBRANE ENTIRETY IN IRON- DEFICIENCY ANEMIA
}

Sevgi Yetgin a; Deniz Aslan b; Sule Unal a; Betül Tavil a; Bar Kukonmaz a; Selin Aytaç Elmas a; Lale Olcay c; Duygu Uçkan Çetinkaya a

a Faculty of Medicine, Department of Pediatrics, Division of Pediatric Hematology, Hacettepe University, Ankara, Turkey ${ }^{b}$ Faculty of Medicine, Department of Pediatrics, Division of Pediatric Hematology, Gazi University, Ankara, Turkey c Dr. A. Y. Oncology Training and Research Hospital, Ankara, Turkey

Online Publication Date: 01 August 2008

To cite this Article Yetgin, Sevgi, Aslan, Deniz, Unal, Sule, Tavil, Betül, Kukonmaz, Bar, Elmas, Selin Aytaç, Olcay, Lale and Çetinkaya, Duygu Uçkan(2008)'DYSPLASIA AND DISORDER OF CELL MEMBRANE ENTIRETY IN IRON-DEFICIENCY ANEMIA',Pediatric Hematology and Oncology,25:6,492 - 501

To link to this Article: DOI: $10.1080 / 08880010802234804$

URL: http://dx.doi.org/10.1080/08880010802234804

\section{PLEASE SCROLL DOWN FOR ARTICLE}

\footnotetext{
Full terms and conditions of use: http://www.informaworld.com/terms-and-conditions-of-access.pdf

This article may be used for research, teaching and private study purposes. Any substantial or systematic reproduction, re-distribution, re-selling, loan or sub-licensing, systematic supply or distribution in any form to anyone is expressly forbidden.

The publisher does not give any warranty express or implied or make any representation that the contents will be complete or accurate or up to date. The accuracy of any instructions, formulae and drug doses should be independently verified with primary sources. The publisher shall not be liable for any loss, actions, claims, proceedings, demand or costs or damages whatsoever or howsoever caused arising directly or indirectly in connection with or arising out of the use of this material.
} 


\title{
DYSPLASIA AND DISORDER OF CELL MEMBRANE ENTIRETY IN IRON-DEFICIENCY ANEMIA
}

\author{
Sevgi Yetgin $\square$ Hacettepe University, Faculty of Medicine, Department of Pediatrics, \\ Division of Pediatric Hematology, Ankara, Turkey
}

Deniz Aslan $\square \quad$ Gazi University, Faculty of Medicine, Department of Pediatrics, Division of Pediatric Hematology, Ankara, Turkey

Sule Unal, Betül Tavil, Barış Kuşkonmaz, and Selin Aytaç Elmas $\square \quad$ Hacettepe University, Faculty of Medicine, Department of Pediatrics, Division of Pediatric Hematology, Ankara, Turkey

Lale Olcay $\square \quad$ Dr. A. Y. Oncology Training and Research Hospital, Ankara, Turkey

Duygu Uçkan Çetinkaya $\square \quad$ Hacettepe University, Faculty of Medicine, Department of Pediatrics, Division of Pediatric Hematology, Ankara, Turkey

\begin{abstract}
$\square \quad$ Peripheral blood smears of 43 patients (26 males, median age 18 months, range: 6-180 months) with nutritional iron-deficiency anemia (IDA) were examined for the presence of trilineage hematological dysplasia. Twelve patients were reexamined for dysplastic findings after achieving $a$ normal $\mathrm{Hb}$ and hematocrit level for age by the end of 2-3 months of iron treatment. A control group of 17 age-matched healthy children were also included. Neutrophils with loss of membrane entirety and protrusions were remarkable in 34/43 (79\%) in the IDA group versus $1 / 12$ (8\%) after iron treatment and none of the control group. Microspherocytes were seen in 9/43 (21\%) of IDA patients. Additionally, trilienage dysplasia was observed in the bone marrow samples available in 3 of the patients. It has been shown that iron-deficiency results in cellular DNA and RNA alterations, cellcycle G1/S phase arrest, and apoptosis. Rac GTPases have been shown to control actin cytoskeleton, influencing cell polarity, microtubule dynamics, and the cytoskeletal organization of hematopoietic cells. Thus, the findings described above in neutrophils and red cells suggest a plausible link between iron and the Rac GTPase gene family. It may be a new avenue for iron waiting for proof.
\end{abstract}

Keywords anemia, dysplasia, iron

Received 16 April 2007; accepted 2 May 2008.

Dr. Yetgin designed the research; Dr. Yetgin, Dr. Aslan, Dr. Unal, Dr. Elmas, Dr. Kuskonmaz, Dr. Tavil, Dr. Olcay, and Dr. Cetinkaya gathered and analyzed data; Dr. Yetgin, Dr. Unal, and Dr. Tavil wrote the paper.

Address correspondence to Prof. Dr. Sevgi Yetgin, Hacettepe University, Faculty of Medicine, Department of Pediatrics, Division of Pediatric Hematology, 06100-Sıhhiye, Ankara, Turkey. E-mail: yetgins@superonline.com 
Iron is a critical nutritional element essential for biological processes, including hematopoietic cell growth and differentiation and gene-expression regulation [1-3]. Iron-deficiency anemia (IDA) is a systemic disorder affecting multiple organ systems in the body. Marked red cell morphologic abnormalities on peripheral blood smear examinations is one of the principal findings of this disease. Neutrophil hypersegmentation, thrombocytopenia has been reported in IDA [1, 2, 4]. Myelodysplasia represents not only neoplastic hematopoiesis in myelodysplastic syndrome (MDS), but also non-neoplastic one in several hematologic disorders. MDS is a multistep process in which several critical defects accumulate and result in clonality and overt cancer [5-7]. MDS can also be polyclonal, and mitochondrial cytopathies may be a model of polyclonal MDS [6, 8]. Most of these polyclonal MDS cases remit spontaneously. In patients with mitochondrial cytopathy-associated MDS, progression to acute leukemia has not been previously described.

Abnormalities of myeloid hemopoietic cells in IDA, such as neutrophil hypersegmentation and also dysmorphic findings in red blood cells, might be termed as myelodysplasia. These findings also suggest a plausible link between IDA and myelodysplasia. In our clinic we had an experience in a patient with severe IDA who was referred to our center with a possible diagnosis of MDS because of severe dysplasia and anemia. This index case and few previous reports on dysplastic findings, such as neutrophil hypersegmentation and thrombocytopenia in IDA patients, challenged us to examine dysplastic findings in IDA. By this rationale, we examined the hematologic morphology in patients with IDA on a larger perspective. On the basis of the dysplastic hematopoiesis, we observed trilineage dysplasia on peripheral blood and bone marrow (BM) smear examinations in IDA patients.

\section{MATERIALS AND METHODS}

For the purpose of this study 43 patients with IDA were selected. The IDA group consisted of 26 male and 17 female children with a median age of 18 months (range: 6-180). Patients having any infection at the time of or just before the study or chronic diseases other than IDA, malnutrition, and positive bleeding history were excluded from study. Serum vitamin $\mathrm{B}_{12}$, folate, zinc levels, and fecal blood were assessed and found to be normal in all of the patients included in the study. The presence of $\beta$-thalassemia trait was excluded by evaluation of parental blood count values. IDA diagnosis was based on hemoglobin $(\mathrm{Hb})$, mean corpuscular volume (MCV), red cell distribution width (RDW), serum iron (SI), serum iron binding capacity (SIBC), transferrin saturation (TS), and ferritin values that were compatible with IDA according to the age of the patient together with the presence of microcytic hypochromic red cells on the peripheral blood smear. Peripheral blood smears were examined for the presence of trilineage hematological 
dysplasia. Twelve patients could be reexamined for dysplastic findings after achieving a normal $\mathrm{Hb}$ and hematocrit level for age by the end of 2-3 months of iron treatment.

A control group of 17 healthy children at the same age with normal $\mathrm{Hb}$ and red cell indices were also included in the study to compare dysplastic hematologic findings with the IDA group.

The blood count was performed with a Coulter HmX hematology analyzer. Serum iron, iron binding capacity, and ferritin levels were analyzed by D-mode spectrophotometric analysis. The neutrophil examinations were performed on Wright-stained peripheral blood smears. The two experienced morphologists evaluated dysplastic findings by the aid of a multiheaded microscope, concomitantly with strict criteria. The percentage of dysplastic findings was determined counting 100 neutrophils.

The neutrophils were examined for cell size, hypersegmentation ( 5 or more lobe in neutrophils) bizarre nuclei (nuclei with projections, such as hook, club, tag, or microlobe, and pseudo Pelger-Huet-like appearance) and cytoplasmic findings (hypogranularity or agranularity, asymmetrical distribution of granules, cytoplasmic area without granules with darker color, and protrusion from cell membranes or cells that had lost the membrane entirety). Giant platelets were assessed by evaluation at 10 subsequent microscopic areas. Red cell morphology were also recorded.

In 3 patients with IDA in whom bone marrow aspiration have been done, $\mathrm{BM}$ morphology could also be evaluated for the presence of myelodysplasia.

\section{RESULTS}

Patient characteristics, red cell indices, platelet and leukocyte counts with differential ratios of control, and the IDA group before and after iron treatment are summarized in Tables $1 \mathrm{a}$ and $1 \mathrm{~b}$. When compared to the IDA group before treatment, $\mathrm{Hb}$ and hematocrit values were significantly higher and within the normal range in IDA group after treatment $(n=$ 12 ), but MCV and RDW values were still within IDA ranges. Platelet count was also significantly decreased after iron treatment. Mean and range of SI $(26.3 \pm 16.4 ; 1-31 \mu \mathrm{g} / \mathrm{dL})$, SIBC $(418.4 \pm 87.3 ; 280-550 \mu \mathrm{g} / \mathrm{dL})$, and serum ferritin $(4.1 \pm 5.4 ; 1-14 \mathrm{ng} / \mathrm{mL})$ values were within the IDA limits in patients before initiation of treatment. Serum vitamin $\mathrm{B}_{12}$ (536.3 \pm 285.5 : $225-1250 \mathrm{pg} / \mathrm{mL})$, folate $(15.1 \pm 5.8 ; 3.8-20 \mathrm{ng} / \mathrm{mL})$, and zinc $(51.3 \pm 7.4$; $42-60 \mu \mathrm{g} / \mathrm{dL}$ ) levels and fecal blood examination were normal in the IDA group of patients included in the study.

\section{Peripheral Blood Dysmorphism}

In addition to anisocytosis and poikilocytosis, spherocytic red cells were determined in 9 of $43(20 \%)$ patients at peripheral blood smear examinations, although it was not seen in the control group. Neutrophils with 


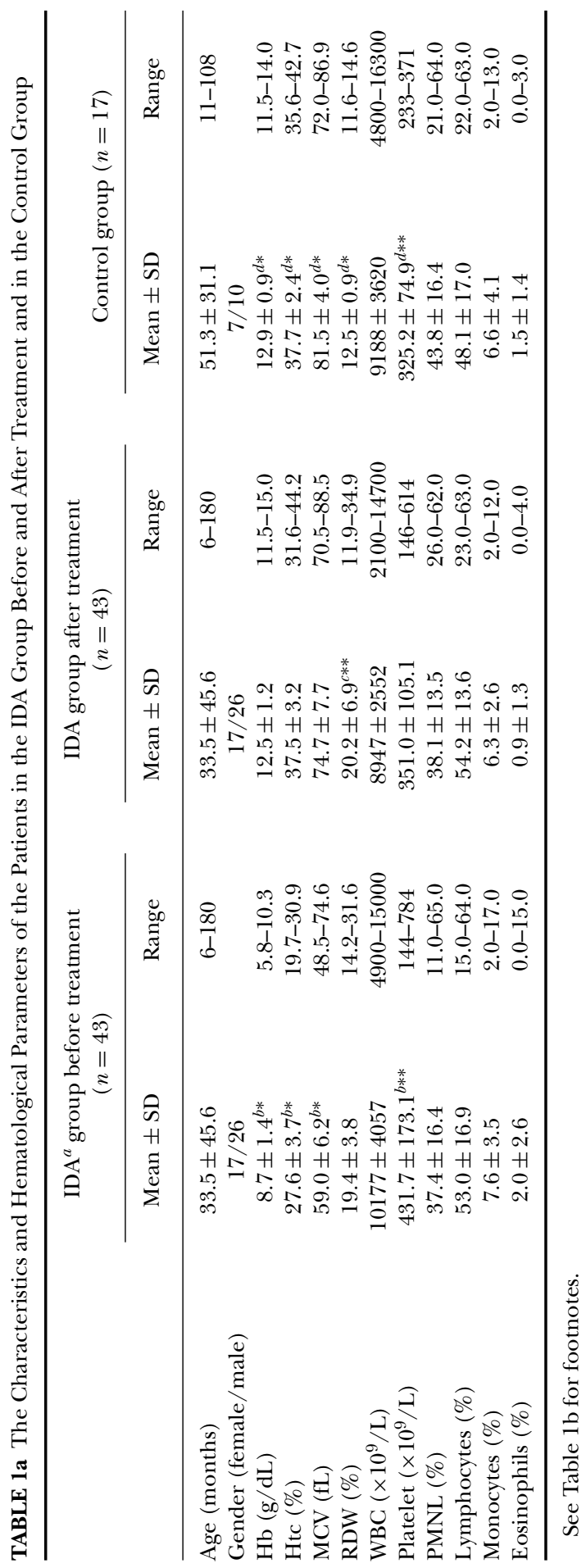




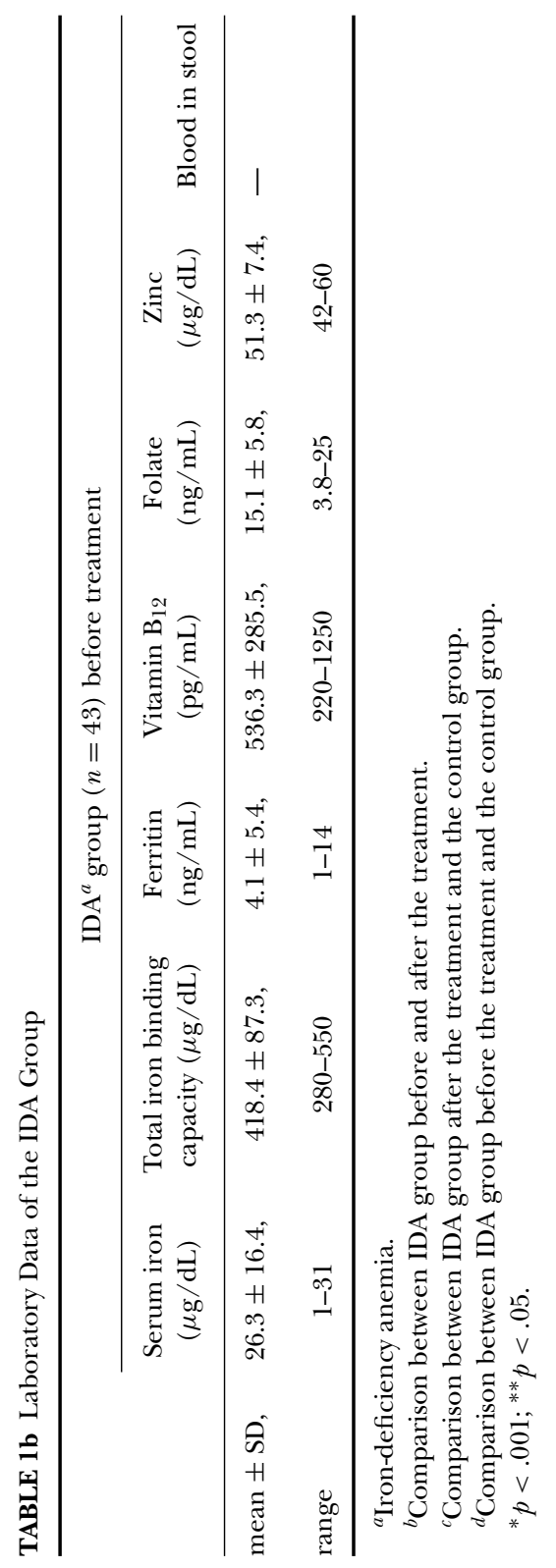


bizarre nuclei were present in $76.7 \%$ of the IDA group before treatment, but only 33 and $30 \%$ of the IDA group after iron treatment and the healthy group were found to have bizarre nuclei, respectively, and the difference was statistically significant $(p<.05)$. Neutrophil hypersegmentation was determined in $67.4 \%$ of children in the IDA group before treatment versus $33.3 \%$ after treatment and $23.5 \%$ in the control group. The finding of dysplastic nuclei with 3 lobes has been observed in eozinophils of IDA group (3 of 43, 6.9\%). Cytoplasmic abnormalities (hypo- or agranularity, asymmetrical granule distribution, blue agranuler cytoplasmic area, and cytoplasmic protrusion by the loss of cell membrane entirety) were also higher in the IDA patient group than in the group of patients treated for anemia and the normal controls $(p<.05)$.

The comparison of dysplastic findings by 100 neutrophil count between IDA and normal control group yielded significantly higher $(p<.05)$ dysplastic findings in IDA group in the following parameters: hypersegmentation $(1.3 \pm 1.5$ versus $0.4 \pm 0.5)$, bizarre nuclei $(2.1 \pm 1.2$ versus $0.85 \pm$ $1.3)$, cytoplasmic abnormalities $(1.2 \pm 1.8$ versus $0.1 \pm 0.4)$, membrane protrusion by the loss of cell membrane entirety (3.2 \pm 3.8 versus 0$)$. Giant platelets $(0.8 \pm 0.4$ versus $0.2 \pm 0.4)$ and thrombocytosis were other findings of dysplasia $(p<.005)$ (Table 2$)$.

TABLE 2 Comparison of the Rate of Patients with Myelodysplastic Features in the IDA Group Before and After Treatment and in the Control Group

\begin{tabular}{|c|c|c|c|c|c|c|}
\hline \multirow[b]{2}{*}{ Parameters } & \multicolumn{2}{|c|}{$\begin{array}{c}\text { IDA }^{a} \text { group } \\
\text { before treatment }\end{array}$} & \multicolumn{2}{|c|}{$\begin{array}{l}\text { IDA group } \\
\text { after treatment }\end{array}$} & \multicolumn{2}{|c|}{ Control group } \\
\hline & $(n=43)$ & $\%$ & $(n=12)$ & $\%$ & $(n=17)$ & $\%$ \\
\hline \multicolumn{7}{|l|}{ Nucleus findings } \\
\hline Hypersegmentation ( 5 or more lobes) & $29^{b *}$ & 67.4 & $4^{c *}$ & 33.3 & $4 / 17^{d *}$ & 23.5 \\
\hline $\begin{array}{l}\text { Bizarre nucleus (nucleus with } \\
\text { projections, hooks, clubs, tags or } \\
\text { microlobes, and Pelger-Huet } \\
\text { abnormality) }\end{array}$ & $33^{b *}$ & 76.7 & $4^{c * *}$ & 33.3 & $5 / 17^{d *}$ & 29.4 \\
\hline $\begin{array}{l}\text { Cytoplasmic findings } \\
\text { (Hypo or agranulation and granule } \\
\text { distribution abnormality) }\end{array}$ & $20^{b * *}$ & 46.5 & $3^{c *}$ & 25 & $1 / 17^{d *}$ & 14.3 \\
\hline Membrane abnormality & $34^{b *}$ & 79.1 & $1^{c *}$ & 8.3 & $0 / 17^{d *}$ & - \\
\hline Giant thrombocytes & $35^{b *}$ & 81.4 & $5^{c * *}$ & 41.6 & $4 / 17^{d *}$ & 23.5 \\
\hline $\begin{array}{l}\text { Erythrocyte abnormality } \\
\quad \text { (microspherocytes, poikilocytosis) }\end{array}$ & $9^{b *}$ & 20.9 & 0 & - & $0 / 17$ & - \\
\hline $\begin{array}{l}{ }^{a} \text { Iron-deficiency anemia, } \\
{ }^{b} \text { Comparison between IDA group be } \\
{ }^{c} \text { Comparison between IDA group aft } \\
{ }^{d} \text { Comparison between IDA group be } \\
{ }^{*} p<.001 ;{ }^{* *} p<.05 .\end{array}$ & $\begin{array}{l}\text { and after } \\
\text { reatment at } \\
\text { e treatment }\end{array}$ & $\begin{array}{l}\text { eatmer } \\
\text { d the } c \\
\text { ind the }\end{array}$ & $\begin{array}{l}\text { ntrol group } \\
\text { control gro }\end{array}$ & & & \\
\hline
\end{tabular}




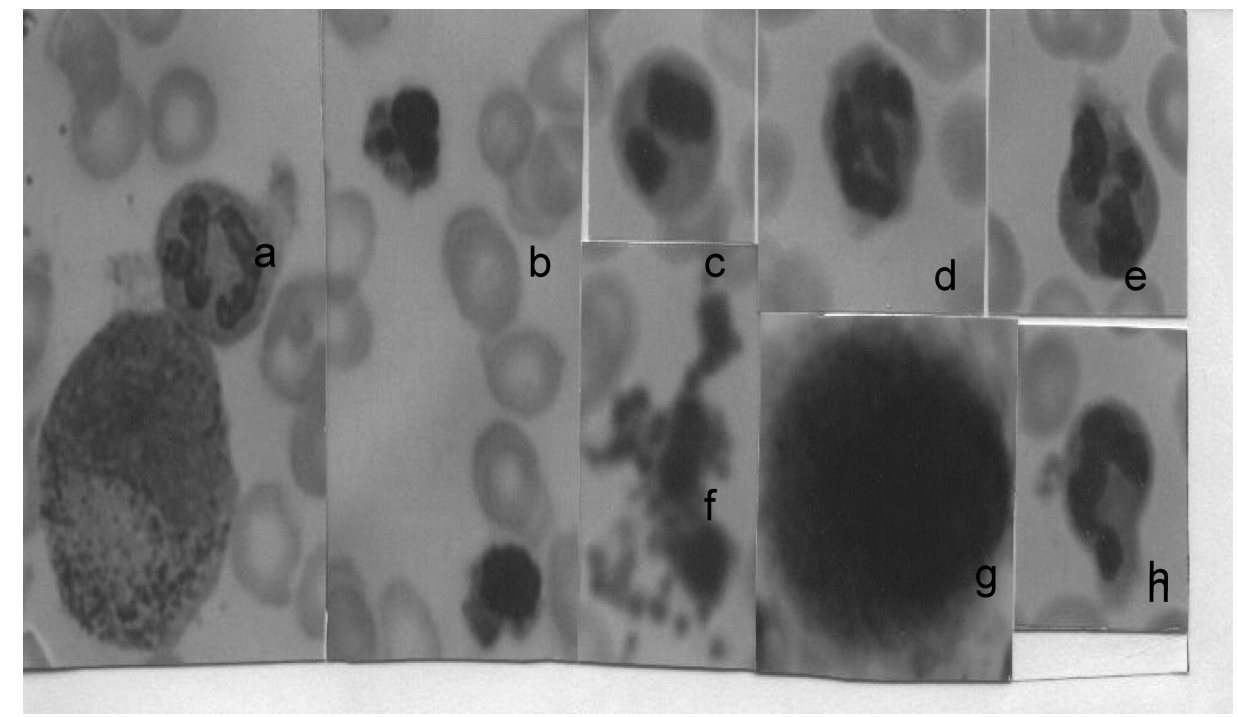

FIGURE 1 Dysplastic changes are summarized: a, d, e, h: membrane protrusion, loss of membrane entirety; b: dysplastic nuclei of normoblasts; c: Pelger-Huet anomaly; d: hypersegmentation in neutrophil; f: giant platelets; g: micromegakaryocyte.

\section{BM Dysmorphism}

Dysplastic changes were especially prominent in erythroid precursors and megakaryocytes. Abnormal nuclei such as bilobed, three-lobed, or irregular form and megaloblastoid normoblasts were also determined. Megakaryocytes were found to be increased and multiple micromegakaryocytes were observed. Dysmorphic findings of the myeloid lineage, such as cytoplasmic hypogranulation and asymmetrical granule dystributions, were also present, but they were not as striking as that of erythroid and megakaryocytic dysplasias.

In Figure 1, some of the impressive dysplastic findings of IDA patients are illustrated.

\section{DISCUSSION}

This study presents the dysplastic hematological changes in peripheral blood and BM of IDA patients. Myelodysplastic changes refer to abnormal morphology of the BM and/or peripheral blood and this feature is commonly seen in MDS. Myelodysplasia in peripheral blood and BM can also be seen in different conditions such as autoimmune diseases, infections, especially viral infections, immunosuppressive drugs, chromosomal abnormalities, and DNA abnormalities [9-20]. Iron deficiency results in cellular metabolic enzyme changes, alterations in cellular growth, DNA, RNA, and protein structure, and also increased susceptibility to infections 
$[1,2,21]$. Hypersegmentation has been reported in IDA patients previously [22], and in the present study additional dysplastic findings other than hypersegmentation were reported.

Patients included in the study answered questions about infection, any other comorbid disease, drug administration, and vitamin $\mathrm{B}_{12}$ and folate deficiency. Giant platelets were not related to an associated autoimmune disease [13] or bleeding history and the patients were also examined for the presence of blood in the stool, which may cause consumption of plateles.

Iron deficiency results in dysplastic abnormalities of nails, hair, and skin, in which the cells have an enormous proliferative capacity similar to hematopoietic cells [23]. DNA defects and cell cycle disorders like G1/S phase cell cycle arrest and apoptosis as opposed to differentiation have been observed after iron deprivation [3,7]. Iron deficiency may result in incomplete processing of DNA and abnormal morphologic features in the cells with high proliferative capacity. In our study, an interesting finding was the loss of cell membrane entirety resulting in protrusion of cell cytoplasm. Spherocytic red cells were unexpectedly found in IDA patients. Recently, it was shown that Rac1 and Eac2 GTPase deficiency in mice alters actin assembly in red cells and causes microcytic hemolytic anemia with bizarrely shaped microspherocytes. Rac controls actin cytoskeleton, influences cell polarity and motility and microtubule dynamics, and regulates cell survival, G1 cell-cycle progression, and transcription [24]. These findings implies that Rac GTPases interfere with the cytoskeletal organization of hematopoietic cells. By this rationale, our findings of microspherocyte, loss of membrane entirety, and cytoplasmic protrusion of neutrophils might be explained by Rac actions in IDA. This interaction needs to be proved by experimental studies, since iron is involved in gene expression regulation. Dysplastic morphology might be observed in conditions of bone marrow activation such as in hemolytic processes or bleeding. Reticulocyte levels in our patients were not indicative of a hemolytic disease and compatible with nutritional IDA. Erythropoietin levels increase in IDA and we know that erythropoietin may also be involved myelopoietic cell activation in all lineages. This may also be a causative factor of dysplastic morphology.

After IDA treatment peripheral blood smears were also examined in patients in whom $\mathrm{Hb}$ levels achieved normal values, whereas MCV and RDW levels were still in IDA ranges. Additionally, although dysplastic findings in peripheral blood were found to be decreased after iron treatment, they were still significantly more prominent than normal controls. This might indicate that dysplasia correction competes with IDA correction.

In MDS, iron status may be a functional deficiency and may explain partly the dysplastic changes. The defects in the steps of heme biosynthesis that occur within the mitochondrion produce sideroblastic anemias. The signal feature of sideroblastic anemia is mitochondrial iron deposition. Sideroblasts show normal iron uptake, but subsequent poor incorporation 
into heme. Acquired sideroblastic anemias are much more frequent than the hereditary forms. The refractory anemia with ring sideroblasts (RARS) manifest in both the early and late erythroid precursors. Gattermann et al. [25] described at least two point mutations in mitochondrial DNA of patients with acquired sideroblastic anemia causing respiratory chain dysfunction, thereby impairing reduction of ferric iron to ferrous iron. As far as functional iron deficiency causes the dysplastic findings in these patients, we can also expect to find dysplasia in quantitative deficiencies of iron.

The causal relationship of myelodysplastic changes in IDA may be explained by interaction of multifactors such as cellular metabolic enzyme changes, cell growth and differentiation, and gene expression regulation. The ineffective utilization of folate along with vitamin $\mathrm{B}_{12}$ may also have an additive effect on the dysplasia observed in IDA.

As far as we know, the detailed trilineage dysplastic features have not been reported in iron-deficiency anemia previously. Our morphologic observation in peripheral blood and BM smears of IDA patients is an additional finding.

\section{REFERENCES}

[1] Andrews NC, Bridges KR. Disorders of iron metabolism and sideroblastic anemia. In: Nathan DG, Orkin SH, eds. Nathan and Oski's Hematology of Infancy and Childhood. Philadelphia: WB Saunders; 1998:423-462.

[2] Lanzkowsky P. Iron deficiency anemia. In: Manual of Pediatric Hematology and Oncology. New York: Churchill Livingstone; 1995:35-50.

[3] Alkantara O, Kalidas M, Baltathahis J, Boldt DH. Expression of multiple genes in differentiating hematopoietic cells is dependent on iron. Exp Hematol. 2002;29:1060-1069.

[4] Westerman DA, Evans D, Metz J. Neutrophil hypersegmentation in iron deficiency anemia: a case-control study. Br J Hematol. 1999;107:512-515.

[5] Gadner H, Haas OA. Experience in pediatric myelodysplastic syndromes. Hematol Oncol Clin North Am. 1992;6:655-672.

[6] Bader-Meunier B, Mielot F, Tchermia G, et al. Myelodysplastic syndromes in childhood: report of 49 patients from a French multicenter study. Br J Haematol. 1996;92:344-350.

[7] Steensma DP, Tefferi A. The myelodysplastic syndromes: a perspective and review highlighting current controversious. Leuk Res. 2003;27:95-120.

[8] Basis JB. Should mitochondrial cytopathies be classified as myelodysplastic syndromes? $\mathrm{Br} \mathrm{J}$ Haematol. 1996;94:767-769.

[9] Herrod H, Dow L, Sullivan J. Persistent Epstein-Barr virus infection mimicking juvenilc chronic myleogeneous leukemia: immunologic and hematologic studies. Blood. 1983;61:1098-1104.

[10] Lorenzana A, Lyons H, Sawaf H, Higgins M, Carrigan D, Emmanuel P. Human herpes virus-6 infection mimicking juvenile chronic myelogenous leukemia in an infant. J Pediatr Hematol Oncol. 2002;24:136-141.

[11] Kirby M, Weitzinan S, Freedman M. Juvenile chronic myelogeneous leukemia: differentiation from infantile cytomegalovizas infection. Am J Pediatr Hematol Oncol. 1990;12:292-296.

[12] Pinkel D. Differentiating juvenile myelomonocytic leukemia from infectious disease. Blood. 1998;91:365-367.

[13] Olcay L, Yetgin S, Okur H, Erekul S, Tuncer M. Dysplastic changes in idiopathic thrombocytopenic purpura and the effect of corticosteroids increase dysplasia and cause hyperdiploid macropolycytes. Am J Hematol. 2000;65:99-104. 
[14] Yetgin S, Özen S, Saatçi Ü, Bakkaloğlu A, Beşbaş N, Kirel B. Myelodsplastic features in juvenile rheumatoid artritis. Am J Hematol. 1997;54:166-169.

[15] Yetgin S, Ozen S, Yenicesu S, Cetin M, Bakkaloğlu A. Myelodysplastic features in polyatritis nodasa. Pediatr Hematol Oncol. 2001;18:157-160.

[16] Yetgin S, Çetin M, Yenicesu J, Özaltın F, Uçkun D. Acute parvovirus-B19 infection mimicking juvenile myelomonocytic leukemia. Eur J Haematol. 2000;64:1-3.

[17] Baaurmann H, Schwarz TF, Oertel J, Serke S, Roggendorf M, Hukin D. Acute parvovirus B19 infection mimicking myelodysplastic syndrome of bone marrow. Ann Hematol. 1992;64:43-45.

[18] Rosoff PM. Myelodysplasia and deficiency of uridine diplosphate-galactose 4-epimerase. J Pediatr, 1995;127:605-608.

[19] Louache F, Henri A, Bettaieb A, et al. Role of human immundeficiency virus replication in vitro growth of hematopoietic progenitors. Blood. 1992;80:2991-2999.

[20] Laver JH, Yusuf U, Cantu ES, Barredo JC, Holt LB, Abbound MR. Transient therapy-releated myelodysplastic syndrome assaciated with monosomy 7 and $11 \mathrm{q} 23$ translocation. Leukemia. 1997;11:448-455.

[21] Hershko CH, Karsaı A, Eylon L, Izak G. The effect of chronic iron deficiency on some biochemical functions of the human hemopoietic tissue. Blood. 1970;36:321-329.

[22] Düzgün S, Yildirmak Y, Cetinkaya F. Neutrophil hypersegmentation and thrombocytosis in children with iron deficiency anemia. Turk J Pediatr. 2005;47:251-254.

[23] Sato S. Iron deficiency: structural and microchemical changes in hair, nails, and skin. Semin Dermatol. 1991;10:313-319.

[24] Kalfa TA, Pushkaran S, Mohandas N, et al. Rac GTPases regulate the morphology and deformability of the erythrocyte cytoskeleton. Blood. 2006;108:3637-3645.

[25] Gattermann N, Retzlaff S, Wang YL, et al. Heteroplasmic point mutations of mitochondrial DNA affecting subunit I of cytochrome c oxidase in two patients with acquired idiopathic sideroblastic anemia. Blood. 1997;90:4961-4972. 